
\title{
25 Research Square \\ Litterfall, Decomposition and Nutrient Release in Sacred Forests of Western Odisha, India.
}

Antaryami Pradhan ( $\square$ antaryamipradhan@aiph.ac.in )

AlPH University https://orcid.org/0000-0002-4365-6793

Niranjan Behera

AlPH University

Research

Keywords: Litterfall, litter decomposition, Sacred forests, Ecosystem services, Nutrient cycling

Posted Date: September 14th, 2020

DOI: https://doi.org/10.21203/rs.3.rs-73632/v1

License: (9) This work is licensed under a Creative Commons Attribution 4.0 International License.

Read Full License 


\section{Litterfall, decomposition and nutrient release in sacred forests of western 2 Odisha, India.}

7 Corresponding author:

$8{ }^{1}$ Dr. Antaryami Pradhan

9 School of Biological Sciences

10 AIPH University, Bhhubaneswar

11 Email :antaryamipradhan@aiph.ac.in

12 ORCid: 0000-0002-4365-6793

14 Dr. Niranjan Behera

15 Professor

16 School of Biological Sciences

17 AIPH University, Bhhubaneswar

18 Email: nebehra@aiph.ac.in

\section{Background}

21 Recognizing that litterfall and decomposition are key ecosystem functions for ecosystem stability

22 in a terrestrial ecosystem, litterfall and decomposition in four sacred forests were studied from

23 western part of Odisha. The present study focuses on the detailed aspects of litter dynamics,

24 decomposition and consequent release of nutrients to the forest floor. The results obtained in this

25 study will be beneficial in understanding the ecosystem functioning associated with nutrient 
26 cycling, which helps in determining possible management strategies for optimization of

27 ecosystem functioning and productivity of these sacred forests.

\section{Results}

29 Litterfall and standing litter showed a seasonal pattern with most of the litter accumulated during 30 the dry seasons and lowest in the rainy season. However, no significant difference was observed

31 between the litterfall patterns of the sacred forests. The annual turnover rate $\left(K_{L}\right)$ was found to be

32 in the range of $3.59 / \mathrm{yr}$ to $4.22 / \mathrm{yr}$ in studied sacred forests. The litter decomposition study was

33 performed by litter bag technique and almost $95 \%$ of mass loss was observed within a period of

346 months. Such fast decomposition leads to faster rate of nutrient release across the sites. The 35 studied elements can be set in the following order as regards to their return to the topsoil during 36 decomposition in the order of $\mathrm{K}$ (Potassium) $>\mathrm{N}$ (Nitrogen) $>\mathrm{P}$ (Phosphorus). The approximate 37 amount of nutrient released to the forest soil is quantified in the range of 184.76 to $33.61 \mathrm{~kg} / \mathrm{ha}$ 38 of NPK (Nitrogen, Phosphorus and Potassium) in different sacred forests.

\section{Conclusion}

40 Such nutrient release and dynamics in sacred forests, may contribute an effective nutrient flow to 41 the topsoil as well as to the surrounding agricultural landscapes boosting agricultural 42 productivity and sustainability. This signifies the role of sacred forests in rendering an important 43 ecological service in terms of nutrient cycling.

\section{Keywords:}

45 Litterfall, litter decomposition, Sacred forests, Ecosystem services, Nutrient cycling 


\section{Background}

Plant shed parts of their biomass (litterfall) periodically, which is a key ecological

51 process in terrestrial ecosystems that serves as a linkage between the vegetation and the soil

52 (Vitousek 1984; Lowman 1988; Sayer 2006; Huang et al. 2017; Chakravarty et al. 2019; Zhu et

53 al. 2019). Litter inputs and their decomposition improves the soil structure and function through

54 the soil organic matters and the nutrient pool (Bargali et al. 1993; Yu et al. 2004; Rawat et al.

55 2010; N'Dri et al. 2018). Litterfall and decomposition also contributes to long term carbon

56 storage, ecological restoration and regeneration dynamics (Watanabe et al. 2013; Campos et al.

57 2017; Tian et al. 2017). The presence of litter in the forest floor can potentially increase seedling

58 diversity (Molofsky and Augspurger 1992) and can change plant recruitment rates by creating an

59 insulating layer and reducing soil evaporation and the density of weeds (Facelli and Pickett

60 1991).

Tropical forests are characterized by a strong seasonality in their leaf litterfall pattern

62 (Zhang et al. 2014; Becker et al. 2015; Wagner et al. 2016; Nakagawa et al. 2019), and the

63 seasonality depends on the vegetation characteristics, species composition and plant

64 phenological responses to environmental variation (Cuevas and Lugo 1998; Zalamea and

65 Gonzalez 2008; Schilling et al. 2016; Souza et al. 2019). In tropical dry forests leaf loss mostly

66 occurs during the dry season (Barlow et al. 2007; Zhang et al. 2014). A massive accumulation of

67 litter mass on the forest floor is a common observation in the tropical dry deciduous forest

68 (Murphy and Lugo 1986; Lopes et al. 2015).

In a forest ecosystem the productivity of the tree species depends on the litter

70 decomposition and rapid turnover of litter nutrients (Vendrami et al. 2012; Rai et al. 2016). 
71 Through litter decomposition the complex organic matters in leaf litter disintegrates into simpler

72 form by the action of soil microbial community and enriching the soil with the supply of vital

73 nutrients (Gessner et al. 2010; Rottmann et al. 2010). Nutrient release from the decomposed

74 litter is recognized as an available nutrient ( $\mathrm{Li}$ and $\mathrm{Ye} 2014$ ) for the growth of plant and

75 improvement of soil quality (Maclean and Wein 1978; Moore et al. 2006). Litter decomposition

76 rates vary with the species composition, litter quality, climatic factors and the soil microbial

77 population in different forest types (Krishna and Mohan 2017; Chakravarty et al. 2019).

78 Temperature and precipitation are the prime abiotic factors, whereas litter chemistry and 79 decomposers population in soil are the principal biotic factors in determining litter

80 decomposition rates (Trofymow et al. 2002; Fierer et al. 2005; Davidson and Janssens 2006;

81 Cornwell et al. 2008; Prescott 2010; Berg and McClaugherty 2014).

82 Sacred natural sites including sacred forests and sacred groves have coexisted with

83 human population for centuries. The sacred forests of Odisha represent relatively undisturbed

84 vegetation due to protection by indigenous communities for religious and spiritual values. These

85 sacred forests with rich biodiversity have a stable ecosystem and are considered as biocultural

86 conservation centers (Pradhan and Ormsby 2020). But the ecosystem functioning of the sacred

87 forests in the state of Odisha representing the tropical dry deciduous forest has not been

88 thoroughly studied in terms of litter production and decomposition.

As the litter decomposition is a highly complex process that involves a number of 90 physical, chemical and biological factors, there is little information about the litter 91 decomposition rate and the various factors in forest ecosystems of tropical dry deciduous forests 92 of Odisha. The information related to litterfall and litter decomposition from the sacred forests 93 are also limited to only few studies (Khiwtam and Ramakrishnan 1993; Rajendra Prasad et al. 
94 2000; Pragasan and Parthasarathy 2005). Such studies pertaining to litterfall pattern and the

95 decomposition leading to the carbon enrichment and nutrient cycling are quite essential to boost

96 the ecological processes of the sacred forests. The present study focuses on the detailed aspects

97 of litter dynamics, decomposition and consequent release of nutrients in four sacred forests

98 located in the western part of Odisha, India. The results obtained in this study will be beneficial

99 in understanding the ecosystem functioning associated with nutrient cycling, which helps in 100 determining possible management strategies for optimization of ecosystem functioning and 101 productivity of these sacred forests.

\section{Results}

\section{Dynamics of litterfall production}

105 showed a peak during the month of March. The monthly litter production pattern among the sites 106 did not vary significantly ( $\mathrm{p}$-value $=0.3191)$. The quantum of annual litterfall was the highest in 107 the Medha (11.32 Mg/ha), followed by Dedungri (10.28 Mg/ha), Papanga (8.94 Mg/ha) and least 108 in Andhari (8.59 Mg/ha). In all the sites, the largest proportion of the litter was observed to be 109 the leaf litter with a range of $81-83 \%$. The proportion of litterfall fractions were in order of 110 leaves $>$ twigs $>$ branches $>$ others for all sites.

111 < Insert Figure 3 here>

\section{Standing litter and litter turnover rate $\left(\mathbf{K}_{\mathrm{L}}\right)$}

For each sacred forest the amount of standing litter on the floor showed a pattern

114 identical to that of litterfall. The total standing litter showed the maximum value during March 115 and the minimum value during August and September. The month wise data of standing litter 
116 across the four sacred forests did not vary significantly ( $\mathrm{p}$-value $=0.1884$ ). The mean annual

117 standing litter was observed to be maximum for Medha (2.68 Mg/ha) followed by Dedungri

118 (2.51 Mg/ha), Papanga (2.47 Mg/ha) and least for Andhari (2.39 Mg/ha). The annual turnover 119 rate $\left(K_{L}\right)$ was found to be in the range of 3.59/yr in Andhari to 4.22/yr in Medha. The calculated 120 residence time $(\mathrm{T})$ of litter in different sites varied from 87 to 102 days (Table 3 ) and was ranked 121 in the order Medha $<$ Dedungri $<$ Papanga $<$ Andhari.

122 <Insert Table 3 here>

123 Litter decomposition and Nutrient return

The insitu litter decomposition experiment in the four sacred forests demonstrated a 125 phasic litter decomposition trend (Figure 4). With the progress of time total mass loss was 126 increased but no uniformity was observed in the monthly loss of litter weight. The rate of 127 decomposition was found to be relatively higher in first month then deceased for the second 128 month and then again from third months the rate was found to increase in all forest stands. Litter 129 mass loss across the four sites did not exhibit any significant difference (p-value $=0.9079)$. In 130 all the four sites, about $95 \%$ of the total mass was found to be lost within the six month of the 131 decomposition study. The litter decay rate coefficient (k) varied from 5.75/yr (Andhari and 132 Papanga) to 6.65/yr (Medha). The time taken for 50\% and 99\% decay also varied from 38 to 44 133 days and 274 to 318 days respectively.

134 <Insert Figure 4 here>

The initial chemical characteristics of mixed leaf litter varied significantly among the 136 four sacred forests (except Carbon content) (Table 4). The leaf litter content of Papanga had the 137 highest $\mathrm{N}, \mathrm{P}$ and $\mathrm{K}$ concentration than other forests. On the basis of the relatively higher 
138 concentration of $\mathrm{N}, \mathrm{P}, \mathrm{K}$ and lower ratio of $\mathrm{C}: \mathrm{N}$, the mixed litter of Papanga was considered to 139 be of relatively better quality than others. The litter quality in different sites were in order of 140 Papanga > Dedungri > Andhari > Medha. The monthly variation in nutrients return $(\mathrm{N}, \mathrm{P}, \mathrm{K})$

141 from the litter decomposition followed a pattern that was consistent with the litter mass loss in 142 each forest stand. The rate of nutrient release did not vary significantly $(\mathrm{P}=0.996474)$ among 143 the sites but varied significantly with respect to the months $(\mathrm{P}=0.000136)$. Papanga had the 144 highest percentage of nutrient loss (96.57\%) after the six months of decomposition followed by 145 Andhari (95.36\%), Dedungri (94.18\%) and least in Medha (92.38\%). 147 in the residual litter of all the forest stands. The concentration of $\mathrm{C}$ remains more or less stable in 148 Andhari and Medha but decreased in Dedungri and Papanga. However, the K concentration 149 significantly declined in all the forest stands (Figure 5). The nutrient loss pattern for individual 150 nutrient content suggested no significant difference in the nutrient loss of $\mathrm{C}(\mathrm{P}=0.9836), \mathrm{N}(\mathrm{P}=$ 151 0.9778), $\mathrm{P}(\mathrm{P}=0.7221)$ and $\mathrm{K}(\mathrm{P}=0.9615)$. The nutrient release pattern showed highest release 152 of $\mathrm{K}$ in all the four sites in following order: Andhari $(99.2 \%)>$ Papanga $(99.09 \%)>$ Medha $153(98.84 \%)>$ Dedungri $(98.72 \%)$. Similarly the N loss is in the order of Papanga $(95.08 \%)>$ 154 Andhari $(95.06 \%)>$ Dedungri $(93.58 \%)>$ Medha $(92.26 \%)$. P had the lowest release pattern 155 among the nutrient in all the sites in the order of Papanga (95.34\%) > Andhari (90.72\%) > 156 Dedungri $(88.93 \%)>$ Medha $(80.54 \%)$.

$157<$ Insert Figure 5 here>

On the basis of the litter fall data along with their nutrient contents in different sacred 159 forest sites, the annual return of different nutrients to the forest floor were calculated. The 
160

161

162

163

164

165

166

167

168

169

170

171

172

173

174

175

176

177

178

179

180

181

approximate amount of nutrient released to the forest soil is quantified to be $184.76 \mathrm{~kg} / \mathrm{ha}$ of NPK (Nitrogen, Phosphorus and Potassium) in Papanga, followed by $133.61 \mathrm{~kg} / \mathrm{ha}$ of NPK in Dedungri, $110.85 \mathrm{~kg} / \mathrm{h}$ a of NPK in Medha and least $99.11 \mathrm{~kg} / \mathrm{ha}$ of NPK in Andhari.

\section{Discussion}

The annual litterfall data of different sacred forest sites as estimated in the present study, are within the range of litterfall data of different tropical forests of the world (Zhang et al. 2014). However, the data are noted to be comparatively higher than that of few tropical dry deciduous forests of India (Rai et al. 2016; Shukla et al. 2017). The pattern of monthly litterfall with peak during dry season as observed in the study is in confirmation with patterns noted by Barlow et al. (2007) and Zhang et al. (2014). The observation that the leaves as the largest proportion of the litter $(80-83 \%)$ in the study is in agreement with the findings of Rajendra Prasad et al. (2000), Pragasan and Parhasarathy (2005), Zhang et al. (2014) and Nakagawa et al. (2019), who reported leaf litter as the major fraction of total litter in tropical forests. ecosystem (Spain 1984). Lower range of standing litter mass as noted in the present study is therefore an indication of faster litter turnover rate in different sacred forest sites. There have been several reports about the faster turnover rate of litter in tropical dry/moist deciduous forests (Sanches et al. 2008; Prasangan and Parthasarathy, 2005; Scott et al. 1992; Gholz et al. 2000; Rajendra Prasad et al. 2000).

The leaf litter decomposition did not show significant variation $(\mathrm{P}=0.9923)$ among the sites. This may be due to occurrence of the sites in the same agro-climatic zone, having no significant variation among many of the soil physico-chemical characteristics. Achievement of 
$18295 \%$ weight loss during first six months of the litter decomposition, is in conformation with

183 Swift et al. (1979), who also reported about such trend in dry deciduous forest floor with lateritic

184 soil. However, this rate was faster than the studies from tropical dry forests of Gujrat (Mehta et

185 al. 2013); Subtropical forest of North east India (Devi and Yadava 2010) and tropical dry

186 deciduous forest of Chattisgarh (Bargali et al. 2015) in India. Such faster decomposition usually

187 leads to the faster release of nutrients to soil for further plant uptake (Isaac and Nair 2006) and

188 signifies the relevance and the role of litter in plant nutrition.

189

190

191

192

193

194

195

196

197

198 199 2019).

200 Conclusions

201

202

203

The nutrient release pattern did not show any significant variation among different sites.

However, there observed a difference with respect to the release of types of nutrients in different sites. The release of $\mathrm{K}$ was faster compared to $\mathrm{N}$ and $\mathrm{P}$ during the litter decomposition. This may be due to its high mobility as a leachable cation during decomposition (Peterson and Rolfe 1982; Berg and McClaugherty 2014). The extensive leaching of $\mathrm{K}$ from the leaf litter was also reported by Peterson and Rolfe (1982); Cattanio et al. (2008) and Lanuza et al. (2019). The proportionate nutrient specifically $\mathrm{N}$ and $\mathrm{P}$ in the remaining litter was found to be increase from initial litter content till end of the decomposition period. This may be attributed to microbial or nonmicrobial immobilization of nutrients from the residual leaf litter, during the process of decomposition (Devi and Yadava 2010; Cattanio et al. 2008; Parson and Congdon 2008; Sarkar et al. 2016; Lanuza et al.

The study in general reveals no distinction between the sacred forest and natural forests with respect to the litter production, decomposition and nutrient dynamics. Hence, such people participatory conserved sacred forest sites mimics the attributes of natural forests. The faster 
204 litter decomposition rate with rapid nutrient release pattern in sacred forest sites is expected to 205 supports the optimal levels of soil nutrient pools, which in turn is going to support healthy above 206 ground vegetation and consequently to the ecosystem stability. Besides, such nutrient release and 207 dynamics in sacred forests, may contribute an effective nutrient flow to the surrounding 208 agricultural landscapes boosting agricultural productivity and sustainability. This signifies the 209 role of sacred forests in rendering an important ecological services for the surrounding region. If 210 sacred forests are disturbed, this can affect the ecosystem functioning and stability and may lead 211 to desertification. The dynamics of litter production, decomposition and nutrient release should 212 therefore receive more attention for effective management of the sacred forests.

\section{Methods}

\section{Study Area}

The study was conducted in four different sacred forests of western Odisha: Andhari,

216 Dedungri, Medha and Papanga located in Jharsuguda, Sambalpur, Sundargarh and Bargarh districts

217 respectively (Figure 1).

218 < Insert Figure 1 here>

The detailed information regarding the selected sacred forests, their size, area, associated 221 ethnic gropus and geographical locations are presented in Table 1. The vegetation of these sites 222 can be categorized as tropical dry deciduous types with Shorea robusta Gaertn., 223 Cleistanthus collinus (Roxb.) Benth. Ex Hook. f. Buchanania cochinchinensis (Lour.) M. R. 224 Almeida., Terminalia tomentosa Wight \& Arn, Madhuca longifolia var. latifolia (Roxb.) A. 225 Chev and Lagerstroemia parviflora Roxb as some of the dominant tree species (Pradhan et al. 226 2019). 
228 < Insert Table 1 here>

229 The general climate of the study areas can be considered as Tropical Savanna Climate.

230 Tropical savanna climate is characterized by mean monthly temperature above $18^{\circ} \mathrm{C}$. The rainfall

231 is seasonal i.e. during south-west monsoon from mid of June to end of September. The year is

232 categorized in to 4 seasons viz. winter (Dec-Feb), summer (Mar-May), Monsoon (Jun-Aug) and

233 Post Monsoon (Sep-Nov). During the summer period, the air temperature may go up to as high

234 as $45^{\circ} \mathrm{C}$ with relative humidity value of around $40 \%$. Winter season begins from November to

235 the end of February with December as the coolest month with average temperature of about $13^{\circ}$

236 C. The Average temperature and rainfall data for each of the site have been represented in Figure

2372.

238 < Insert Figure 2 here>

\section{$239 \quad$ Litter sampling and analysis}

240 Litterfall was estimated at monthly interval for a period of one year starting from January 2412017 to Dec 2017. Fifteen traps of $1 \mathrm{~m} \times 1 \mathrm{~m} \times 0.15 \mathrm{~m}$ (length $\times$ breadth $\times$ height) were placed 242 randomly within each sacred forest. The litter was collected throughout the year and were 243 segregated into four fractions, viz., leaf, twig, branch, other parts. The biomass of each 244 components was determined after oven-drying the samples at $80^{\circ} \mathrm{C}$ for 48 hours or until constant 245 weight was achieved.

\section{Litter decomposition}

Nylon bag (Mesh size of $1 \times 1 \mathrm{~mm}$ ) technique was used to study the decomposition of 248 leaf litter of four forest sites (Crossley and Hogland 1962). Fresh leaf litters from all the sites 249 under investigation were randomly collected during the peak litterfall period (February - March) 
250 and air dried. Air dried litter samples of $20 \mathrm{~g}$ each were placed in $20 \mathrm{~cm}$ x $20 \mathrm{~cm}$ litter bags and

251 ninety such bags were prepared for each study sites. Litter bags were placed on the soil surface

252 just below the litter layer and were placed following complete randomized experimental design.

253 At monthly interval 6 bags were recovered from each site. The residual litter from the bag was

254 washed carefully to remove all the soil particles and then oven dried at $80^{\circ} \mathrm{C}$ for 48 hours, 255 weighed and powdered for chemical analysis.

\section{Litterfall Analysis}

257 Annual litterfall data for each site was calculated by summing the monthly data of each 258 plot. Monthly litterfall data was obtained from average value of all litter traps placed in a site. 259 Litter turnover rate $\left(\mathrm{k}_{\mathrm{L}}\right)$ was calculated using mathematical model of Reiners and Reiners (1970)

$$
K_{L}=\frac{L}{X_{L}}
$$

261 Where, $\mathrm{L}=$ annual litterfall $(\mathrm{kg} / \mathrm{ha} / \mathrm{yr})$ and $\mathrm{X}_{\mathrm{L}}=$ Mean annual standing crop $\quad(\mathrm{kg} / \mathrm{ha})$

262 Turnover time $(\mathrm{T})$ was calculated as a reciprocal of turnover rate:

$$
T=\frac{1}{K_{L}}
$$

264 where, $\mathrm{T}$ is time (in year)

265 Organic matter decay constants for the leaf litters were computed using the Olson (1963) 266 negative exponential decay model:

$$
\frac{X}{X_{0}}=\exp (-k t)
$$


268 Where $X$ is the weight remaining at time t, $X_{0}$ is the initial weight, exp is the base of natural $269 \operatorname{logarithm}, k$ is the decay rate coefficient, and $t$ is the time. Further, the time required for $50 \%$ 270 (t50) and 99\% (t99) decay were calculated as per Bockheim et al. (1991).

$$
\begin{gathered}
t_{50}=\frac{0.693}{k} \\
t_{99}=\frac{5}{k}
\end{gathered}
$$

273 The total nutrient return for each site was estimated as the sum of the monthly nutrient return

274 during the study period. Nutrient content of decomposing leaf litter was derived as:

$$
\% \text { Nutrient remaining }=\left(\frac{C}{C_{0}}\right) \times\left(\frac{D M}{D M_{0}}\right) \times 100
$$

276 Where $C$ is the concentration of nutrient in litter at the time of sampling, $C_{0}$ is the concentration

277 of nutrient in the initial litter samples, $D M$ is the mass of litter at the time of sampling, and $D M_{0}$

278 is the mass of initial litter samples kept for decomposition (Bockheim et al. 1991).

\section{Chemical analysis}

All the tree species were considered together as mixed species. All the leaf litter samples

281 collected from the floor as well as from litter bags were washed and dried in oven at $80^{\circ} \mathrm{C}$ for 48

282 hrs, finely ground and stored for nutrient analysis. Total C, N, P and K contents of the tissues and 283 litter material processed above were determined by standard methods. The ash content was 284 determined by igniting $1 \mathrm{~g}$ of powdered litter sample at $550^{\circ} \mathrm{C}$ for 6 hour in a muffle furnace. A 285 total of $50 \%$ of the ash free mass was calculated as the carbon(C) content (Allen 1989). For total $286 \mathrm{~N}$ determination the finely ground samples were digested in a block digester with conc. $287 \mathrm{H} 2 \mathrm{SO} 4$ using Kjeltabs as catalyst and total $\mathrm{N}$ will be determined by distillation and titration 
288 methods ( Allen et al. 1974). Total phosphorus concentration was determined by molybdenum-

289 blue method (Allen et al. 1974) after digestion of samples with tri-acid mixture (H2SO4-HClO4-

290 HNO3). Potassium concentration was determined by flame photometry (Jackson 1958) after

291 digesting the plant samples with tri-acid (H2SO4-HClO4-HNO3) mixture.

\section{Statistical analysis}

293

All the data were checked for normal distribution and homogeneity of variance using

294 Shapiro-Wilk test and Leven's test with stats statistical package in R software platform. Kruskal

295 - Wallis rank sum test was applied to the data if these assumptions were not satisfied. For 296 normalized data two way analysis of variance (ANOVA) performed among the four different 297 sacred forests. Pearson's coefficient was used to test for linear correlation between the monthly 298 litterfall and climatic factors and between mass loss and leaf litter biochemical properties. The 299 packages that used for correlation analysis included corrgram and corrplot. All statistical 300 procedures were performed with $\alpha=0.05$ threshold for significance.

301 < Insert Table 2 here>

302 Declarations:

$303 \quad$ Funding

304 The work was supported by a grant from the Ministry of Environment and Forest, Government 305 of India (MoEF, Govt. of India - vide grant no. 22/19/2011-(SG)/RE, dated 28 March 2012).

306 Conflicts of interest/Competing interests

307 The authors declare no conflicts of interest

308 Availability of data and material

309 The data supported to the conclusions of this article are included within the article. Any quaries 310 regarding these data may be directed to the corresponding author. 


\section{Code availability}

312 Not Applicable

313 Authors' contributions

314 The first author AP conducted the field work and set up the experiment, collected and analyzed

315 the data. The second author NB designed the work and edited the manuscript.

\section{Ethics approval}

317 Not Applicable

\section{Acknowledgements.}

319 We thank the late Professor SP Mishra for guidance and authorities of School of Biological

320 Sciences, AIPH University for allowing publishing the work. We also grateful to Dr. Alison A.

321 Ormsby, University of North Carolina Asheville for her assistance in editing the manuscript.

\section{References}

323 Allen SE (1989) Chemical Analysis of Ecological Materials, $2^{\text {nd }}$ edn. Blackwell Scientific 324 Publications, Oxford.

325 Allen SE, Grimshaw HM, Parkinson JA, Quamby C (1974) Chemical analysis of ecological 326 materials. Black well scientific publications, Oxford, UK.

327 Bargali SS, Singh SP, Singh RP (1993) Pattern of weight loss and nutrients release from 328 decomposing leaf litter in age series of euclayptus plantations. Soil Biol Biochem 25:1731329 1738. https://doi.org/10.1016/0038-0717(93)90177-D

330 Bargali SS, Shukla K, Singh L, Ghosh L, Lakhera ML (2015) Leaf litter decomposition and 331 nutrient dynamics in four tree species of dry deciduous forest. Trop Ecol 56(2):191-200. 
Barlow J, Gardner TA, Ferreira LV, Peres CA (2007) Litterfall and decomposition in primary, secondary and plantation forests in the Brazilian Amazon. For Ecol Manage 247:9197. https://doi.org/10.1016/j.foreco.2007.04.017

Becker J, Pabst H, Mnyonga J, Kuzyakov Y (2015) Annual litterfall dynamics and nutrient deposition depending on elevation and landuse at Mt. Kilimanjaro. Biogeosciences 12:56355646. https://doi.org/10.5194/bg-12-5635-2015

Berg B, McClaugherty C (2014) Plant Litter: Decomposition, Humus Formation, Carbon Sequestration. Springer-Verlag, Berlin Heidelberg.

Bockheim JG, Jepsem EA, Heisey DM (1991) Nutrient dynamics in decomposing leaf litter of four tree species on a sandy soil in Northwestern Wisconsin. Can J For Res 21(6):803-812. https://doi.org/10.1139/x91-113

Campos CA, Cruz HL, Rocha OS (2017) Mass, nutrient pool, and mineralization of litter and fine roots in a tropical mountain cloud forest. Sci Total Environ. 575:876-886. https://doi.org/10.1016/j.scitotenv.2016.09.126

Cattanio J, Kuehne R, Vlek P (2008) Organic material decomposition and nutrient dynamics in a mulch system enriched with leguminous trees in the Amazon. Rev Bras Cienc Solo 32:1073-1086. http://dx.doi.org/10.1590/S0100-06832008000300016 Publisher, India. DOI:10.4018/978-1-7998-0014-9-ch010. 
Cornwell WK, Cornelissen JHC, Amatangelo K et al. (2008). Plant species traits are the predominant control on litter decomposition rates within biomes worldwide. Ecol Lett 11:1065-1071. doi: 10.1111/j.1461-0248.2008.01219.x. Crossley DA, Hoglund MP (1962) A litter bag method for the study of micro arthropods inhabiting leaf litter. Ecology 43:572-573. https://doi.org/10.2307/1933396

Cuevas E, Lugo AE (1998) Dynamics of organic matter and nutrient return from litterfall in stands of ten tropical tree plantation species. For Ecol Manage 112(3):263-279. https://doi.org/10.1016/S0378-1127(98)00410-1

Davidson EA, Janssens IA (2006) Temperature sensitivity of soil carbon decomposition and feedbacks to climate change. Nature 440(7081):165-173. https://doi.org/10.1038/nature04514 Devi NB, Yadava PS (2010) Influence of climate and litter quality on litter decomposition and nutrient release in sub-tropical forest of Northeast India. J For Res 21(2):143-150. https://doi.org/10.1007/s11676-010-0023-1 Facelli JM, Pickett STA (1991) Plant litter: it's dynamics and effects on plant community structure. Bot Rev 57:1-32. https://doi.org/10.1007/BF02858763

\section{$372 \quad$ https://doi.org/10.1016/j.tree.2010.01.010}

373 Gholz HL, Wedin DA, Smitherman SM, Harmon ME, Parton WJ (2000) Long-term 374 dynamics of pine and hard wood litter in contrasting environments: Toward a global model 375 of decomposition. Glob Chang Biol 6(7):751-765. 
Huang Y, Ma Y, Zhao, K, Niklaus PA, Schmid B, He JS (2017) Positive effects of tree species diversity on litterfall quantity and quality along a secondary successional chronosequence in a subtropical forest. J Plant Ecol 10(1):28-35. doi:10.1093/jpe/rtw115 Isaac SR, Nair MA (2006) Litter dynamics of six multipurpose trees in a homegarden in Southern Kerala, India. Agrofor. Syst. 67:203-213. https://doi.org/10.1007/s10457-005-1107-

Jackson ML (1958) Soil Chemical Analysis. Prentice-Hall, Inc., Englewood Cliffs, N.J. Khiewtam RS, Ramakrishnan PS (1993) Litter and fine root dynamics of a relict sacred grove forest at Cherrapunji in north-eastern India. For Ecol Manage 60:327-344. Krishna MP, Mohan M (2017) Litter decomposition in forest ecosystems: a review. Energy Ecology and Environment 2(4):236-249. Lanuza O, Casanoves F, Delgado D, Meersche KV (2019) Leaf litter stoichiometry affects decomposition rates and nutrient dynamics in tropical forests under restoration in Costa Rica. Restor Ecol 27(3):549-558.

Li T, Ye Y (2014) Dynamics of decomposition and nutrient release of leaf litter in Kandelia obovata mangrove forests with different ages in Jiulongjiang Estuary, China. Ecol Eng 73:454-460. litterfall production in the semiarid region of northeastern Brazil. Braz J Biol 75:703-708. Lowman MD (1988) Litterfall and leaf decay in three Australian rainforest formations. J Ecol. 76:451-465.

Maclean DA, Wein RW (1978) Weight loss and nutrient changes in decomposing litter and forest floor material in New Brunswick forest stands. Can J Bot 56:2730-2749. 

Changes in litter decomposition and soil organic carbon in a reforested tropical deciduous cover (India). Ecol Res 28:239-248. Molofsky J, Augspurger CK (1992) The effect of leaf litter on early seedling establishment in a tropical forest. Ecology 73(1):68-77. Moore TR, Trofymow JA, Prescott CE, Fyles J, Titus BD (2006) Patterns of carbon, nitrogen 405 and phosphorus dynamics in decomposing foliar litter in Canadian forests. Ecosystems 9:4662. Murphy PG, Lugo AE (1986) Ecology of Tropical dry forest. Annu Rev Ecol Systemat 9923-9. litterfall in a Bornean tropical rain forest. Ecol Res 34: 31-39.

Olsen JS (1963) Energy storage and the balance of producers and decomposers in ecological systems. Ecology 44:322-331

Parsons S, Congdon R (2008) Plant litter decomposition and nutrient cycling in north Queensland tropical rain-forest communities of differing successional status. J Trop Ecol 24:317-327.

Peterson DL, Rolfe GL (1982) Nutrient dynamics of herbaceous vegetation in upland and flood plain forest communities. Am Midl Nat 107:325-339. 
Pradhan A, Ormsby AA (2020) Biocultural conservation in the sacred forests of Odisha, $423 \quad$ India. Environ Conserv doi:10.1017/S0376892920000181.

424 Pradhan A, Ormsby A, Behera N (2019) Diversity, population structure, and regeneration 425 potential of tree species in five sacred forests of western Odisha, India. Écoscience 26(1): 426 2376-7626. https://doi.org/10.1080/11956860.2018.1522148.

427 Pragasan LA, Parthasarathy N (2005) Litter production in tropical dry evergreen forests of 428 south India in relation to season, plant life forms and physiognomic groups. Curr Sci $429 \quad 88(8): 1255-1263$.

430 Prescott C (2010) Litter decomposition: what controls it and how can we alter it to sequester 431 more carbon in forest soils? Biogeochemistry 101:133-149.

432 Rai A, Singh AK, Ghosal N, Singh N (2016) Understanding the effectiveness of litter from 433 tropical dry forests for the restoration of degraded lands. Ecol Eng 93:76-81.

434 Rajendraprasad M, Krishnan PN, Pushpangadan P (2000) Vegetational characterisation and 435 litter dynamics of the sacred groves of Kerala, southwest India. J Trop For Sci 12(2):320$436 \quad 335$.

437 Rawat N, Nautiyal BP, Nautiyal MC (2010) Litter decomposition rate and nutrient release 438 from different litter forms in a Himalayan alpine ecosystem. Environmentalist 30(3):279-288. 439 Reiners WA, Reiners NM (1970) Energy and Nutrient dynamics of forest floors in three $440 \quad$ Minnesota forests. J Ecol 58:497-519.

441 Rottmann N, Dyckmans J, Joergensen RG (2010) Microbial use and decomposition of maize 442 leaf straw incubated in packed soil columns at different depths. Eur J Soil Biol 46:27-33. 
Sanches L, Valentini CMA, Junior OBP, et al. (2008) Seasonal and inter annual litter dynamics of a tropical semideciduous forest of the southern Amazon Basin, Brazil. J Geophys Res 113: G04007, doi:10.1029/2007JG000593.

Sarkar M, Devi A, Nath M (2016) Foliar litter decomposition of four dominant tree species

447 in the Hollongapur Gibbon Wildlife Sanctuary, Assam, Northeast India. Cur Sci 111(4):747-

448

449

450

451

452

453

454

455

456

457

458

459

460

461

462

463 753.

Sayer EJ (2006) Using experimental manipulation to assess the roles of leaf litter in the functioning of forest ecosystems. Biol Rev Camb Philos Soc 81:1-31.

Schilling EM, Waring BG, Schilling JS, Powers JS (2016) Forest composition modifies litter dynamics and decomposition in regenerating tropical dry forest. Oecologia 182:287-297.

Scott DA, Proctor J, Thompson J (1992) Ecological studies on a lowland evergreen rain forest on Maraca Island, Roraima, Brazil.II. litter and nutrient cycling. J Ecol 80:705-717.

Shukla AK, Srivastava PK, Singh B, Behera SK, Thomas T (2017) Litterfall patterns and soil nutrient chemistry in varied tropical deciduous forests. Int J Chem Stud 5:1203-1210.

Souza SR, Veloso MDM, Espirito-Santo MM, Silva JO, Sanchez-Azofeifa A, Brito BGS, Fernandes GW (2019) Litterfall dynamics along a successional gradient in a Brazilian tropical dry forest. For Ecosyst 6:35. https://doi.org/10.1186/s40663-019-0194-y.

Sapin AA (1984) Litterfall and standing crop of litter in three tropical Australian rainforests. J Ecol 72(3): 947-961.

Swift MJ, Heal OW, Anderson JM (1979) Decomposition in terrestrial ecosystems. Appl Phys Lett 83:2772-2774. 
Tian L, Zhao L, Wu X, Fang H, Zhao Y, Yue G, Liu G, Chen H (2017) Vertical patterns and controls of soil nutrients in alpine grass land: implications for nutrient uptake. Sci. Total Environ. 607:855-864.

467 Trofymow JA, Moore TR, Titus B et al. (2002) Rates of litter decomposition over 6 years in 468 Canadian forests: influence of litter quality and climate. Can J For Res 32:789-804

469 Vendrami JL, Jurinitz CF, Castanho CT, Lorenzo L, Oliveira AA (2012) Litterfall and leaf 470 decomposition in forest fragments under different successional phases on the Atlantic Plateau 471 of the state of Sao Paulo, Brazil. Biota Neotrop 12: http://www.biotaneotropica.org.br/v12n3/en/abstract? article +bn03312032012. Vitousek PM (1984) Litterfall, nutrient cycling, and nutrient limitation in tropical forests. $474 \quad$ Ecology 65:285-298.

475 Wagner FH, Hérault B, Bonal D, Stahl C, Anderson LO, Baker TR et al. (2016) Climate 476 seasonality limits leaf carbon assimilation and wood productivity in tropical forests. 477 Biogeosciences 13:2537-2562.

478 Watanabe T, Fukuzawa K, Shibata H (2013) Temporal changes in litterfall, litter 479 decomposition and their chemical composition in Sasa dwarf bamboo in a natural forest 480 ecosystem of northern Japan. J. For. Res 18(2):129-138.

481 Yu SY, Jian FG, Guang SC, Jin SX, Li PC, Lin P (2004) Litterfall, nutrient return, and leaf482 litter decomposition in four plantations compared with a natural forest in subtropical China. $483 \quad$ Ann For Sci 61(5):465-476.

484 Zalamea M, González G (2008) Leaffall phenology in a subtropical wet forest in Puerto 485 Rico: from species to community patterns. Biotropica 40:295-304. 
Zhang H, Yuan W, Dong W, Liu S (2014) Seasonal patterns of litterfall in forest ecosystem worldwide. Ecol Complex 20:240-247. Zhu X, Liu W, Chen H, Deng Y, Chen C, Zeng H (2019) Effects of forest transition on litterfall, standing litter and related nutrient returns: Implications for forest management in Tropical China. Geoderma 333:123-134.

491

492 Table 1. Sacred forest sites with their geographical location, associated deities and tribes.

\begin{tabular}{|lllll|}
\hline Sacred forests & Approx. Size & District & Deity & Assoc. Tribes \\
\hline Andhari & 1000 ha & Jharsuguda & Andhari & Gond \\
Dedungri & 50 ha & Sambalpur & Manchaka Rishi & Gond \\
Medha & 25 ha & Sundargarh & Shiva & Bhuya, Jhara \\
Papanga & 250 ha & Bargarh & Budharaja & Bhil \\
\hline
\end{tabular}


Table 2. Soil physico chemical attributes of $(0-30 \mathrm{~cm})$ in four tropical dry deciduous sacred

511 forests

\begin{tabular}{|lcccccc|}
\hline \multicolumn{1}{c}{ Soil parameters } & Andhari & Dedungri & Medha & Papanga & p-value & Significance \\
\hline $\mathrm{pH}$ & 5.81 & 5.87 & 5.94 & 5.59 & 0.07622 & NS \\
Electron conductivity & 0.2 & 0.19 & 0.13 & 0.21 & 0.2498 & NS \\
Moisture (\%) & 6.08 & 5.81 & 6.40 & 6.67 & 0.9679 & NS \\
Carbon (\%) & 2.41 & 2.00 & 2.08 & 0.95 & 0.009408 & $* * *$ \\
Nitrogen (\%) & 0.17 & 0.16 & 0.15 & 0.06 & 0.002591 & $* * *$ \\
Phosphorus (Kg/ha) & 7.61 & 14.12 & 14.52 & 38.48 & $3.36 \mathrm{e}-06$ & $* * *$ \\
Potassium (Kg/ha) & 197.75 & 195.61 & 192.66 & 199.85 & 0.9349 & NS \\
C:N & 14.87 & 13.50 & 14.47 & 14.77 & 0.6328 & NS \\
\hline
\end{tabular}

512 
Table 3. Annual litterfall and turnover rates in different sacred forests.

\begin{tabular}{|lcccc|}
\hline \multicolumn{1}{|c}{ Parameters } & Andhari & Dedungri & Medha & Papanga \\
\hline Annual litterfall $(\mathrm{Mg} / \mathrm{ha} / \mathrm{yr})$ & 8.59 & 10.28 & 11.32 & 8.94 \\
Mean annual standing crop $\left(\mathrm{X}_{\mathrm{L}}\right)(\mathrm{Mg} / \mathrm{ha})$ & 2.39 & 2.51 & 2.68 & 2.47 \\
Litter turnover rate $\left(\mathrm{K}_{\mathrm{L}}\right)$ & 3.59 & 4.10 & 4.22 & 3.62 \\
Turnover time in year $(\mathrm{T})$ & 0.278 & 0.244 & 0.237 & 0.276 \\
Residence time in days & 102 & 89 & 86 & 101 \\
Decay rate coefficient $(\mathrm{k})$ & 6.65 & 6.12 & 5.75 & 6.65 \\
Time required for 50\% decomposition in years & 0.10 & 0.11 & 0.12 & 0.10 \\
( $\left.\mathrm{t}_{50}\right)$ & & & & \\
Time required for 99\% decomposition in & 0.75 & 0.82 & 0.87 & 0.75 \\
years ( $\left.\mathrm{t}_{99}\right)$ & & & & \\
\hline
\end{tabular}

529

530

531 
544 Table 4. Initial biochemical constituents of litter collected from different sacred forests.

\begin{tabular}{|lcccccc|}
\hline Leaf properties & Andhari & Dedungri & Medha & Papanga & p-value & Significance \\
\hline$\% \mathrm{C}$ & $47 \pm 0.63$ & $46.67 \pm 0.52$ & $46.67 \pm 0.52$ & $46 \pm 1.55$ & 0.5159 & $\mathrm{NS}$ \\
$\% \mathrm{~N}$ & $0.59 \pm 0.03$ & $0.63 \pm 0.07$ & $0.54 \pm 0.05$ & $0.68 \pm 0.06$ & 0.006546 & $* * *$ \\
$\% \mathrm{P}$ & $0.26 \pm 0.08$ & $0.31 \pm 0.02$ & $0.18 \pm 0.02$ & $0.71 \pm 0.03$ & 0.0001977 & $* * *$ \\
$\% \mathrm{~K}$ & $0.36 \pm 0.05$ & $0.44 \pm 0.05$ & $0.34 \pm 0.07$ & $0.75 \pm 0.03$ & 0.0006696 & $* * *$ \\
$\mathrm{C} / \mathrm{N}$ & $79.58 \pm 3.69$ & $74.78 \pm 7.97$ & $87.17 \pm 9.48$ & $68.22 \pm 5.60$ & 0.006239 & $* * *$ \\
$\mathrm{C} / \mathrm{P}$ & $192.19 \pm 49.39$ & $152.96 \pm 8.83$ & $268.72 \pm 26.73$ & $64.65 \pm 3.86$ & 0.0001977 & $* * *$ \\
$\mathrm{~N} / \mathrm{P}$ & $2.41 \pm 0.59$ & $2.07 \pm 0.29$ & $3.13 \pm 0.59$ & $0.95 \pm 0.11$ & 0.0004914 & $* * *$ \\
\hline
\end{tabular}

545

546

547

548

549

550

551

552

553

554

555

556 


\section{Lists of Figure}

564 Figure 1. Location of Study sites in four different districts (Sundergarh, Jharsuguda, Sambalpur 565 and Bargarh) of Odisha.

566 Figure 2. Average monthly temperature and rainfall of the study sites for 2017.

567 Figure 3. Monthly variation of litterfall $\left(\mathrm{g} / \mathrm{m}^{2}\right)$ in different sacred forests.

568 Figure 4. Trends of remnant litter mass and nutrients during the period of decomposition in 569 different sites; A) Mass remains, B) Nutrient remains.

570 Figure 5. Nutrient loss or remains during the decomposition period.

571

572

573

574

575

576

577

578

579

580

581 

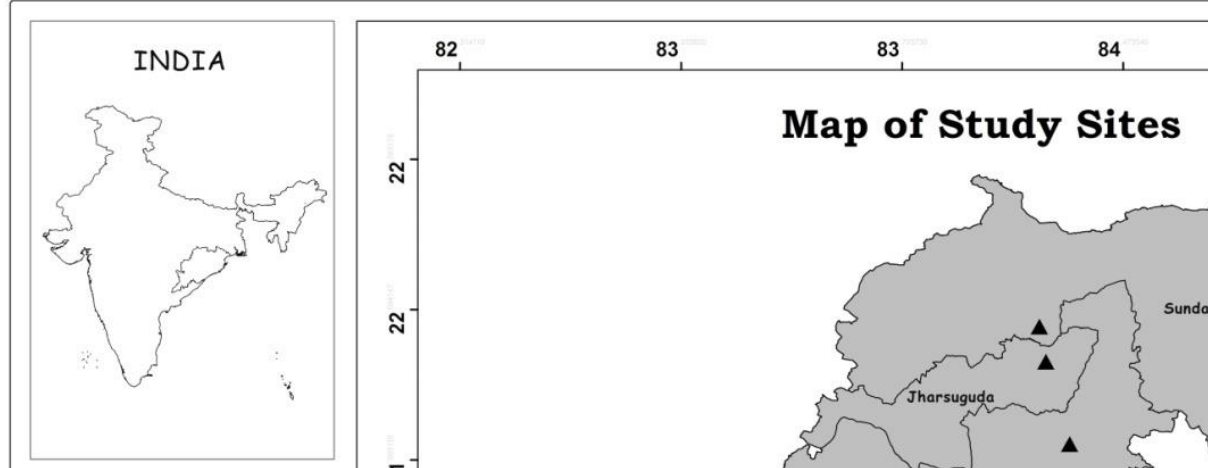

85

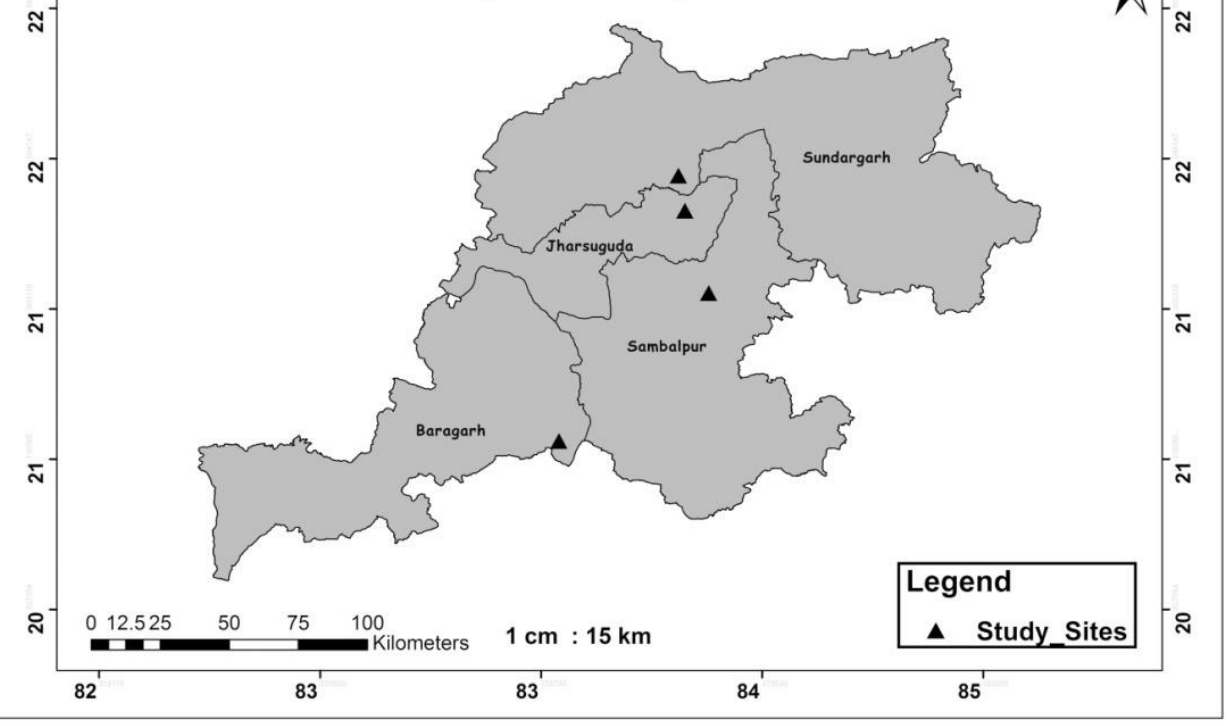

587

Figure 1. Location of Study sites in four different districts (Sundergarh, Jharsuguda,

588 Sambalpur and Bargarh) of Odisha.

589

590

591

592

593

594

595

596

597 


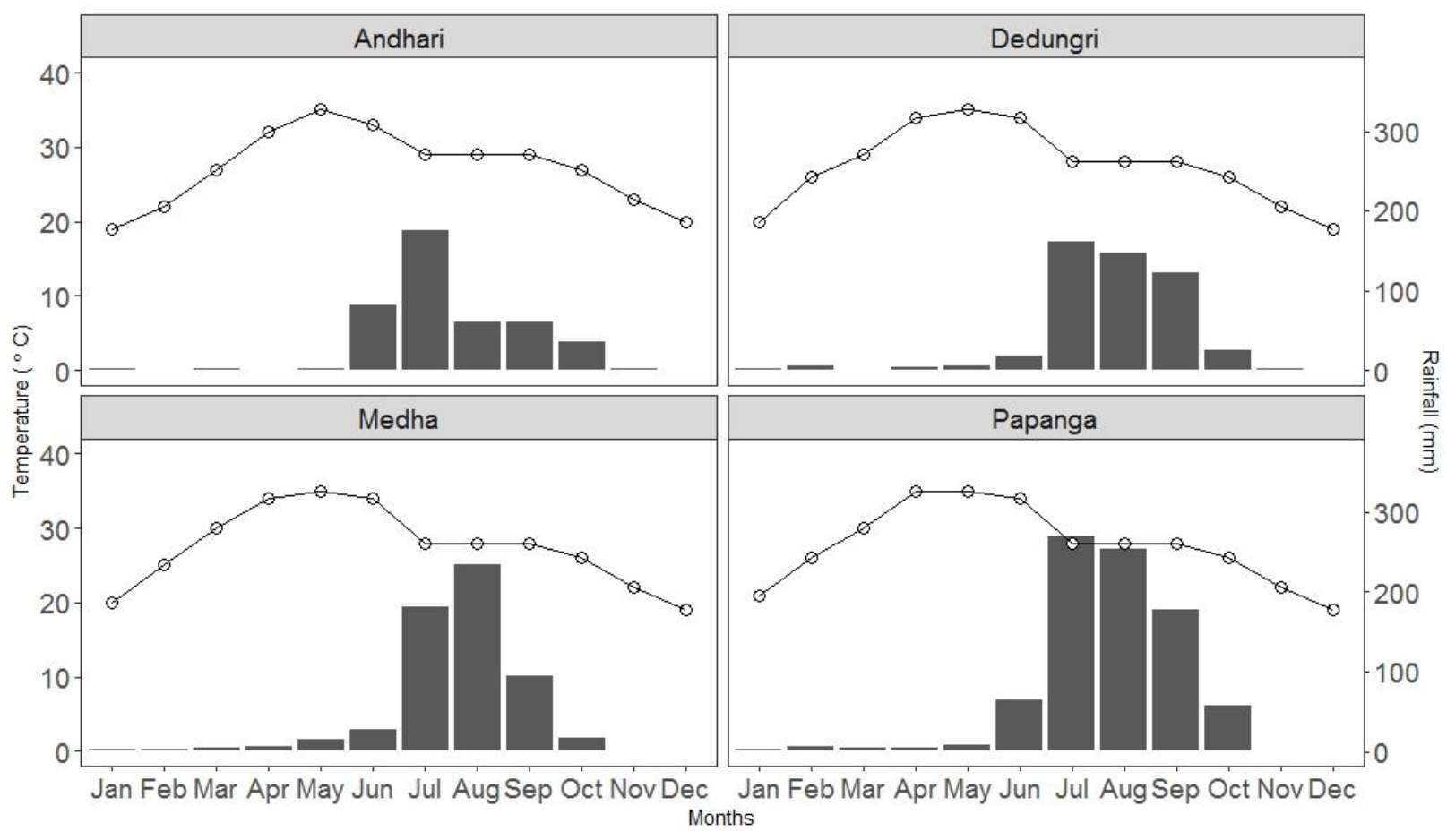

601 Figure 2. Average monthly temperature and rainfall of the study sites for 2017.

602

603

604

605 


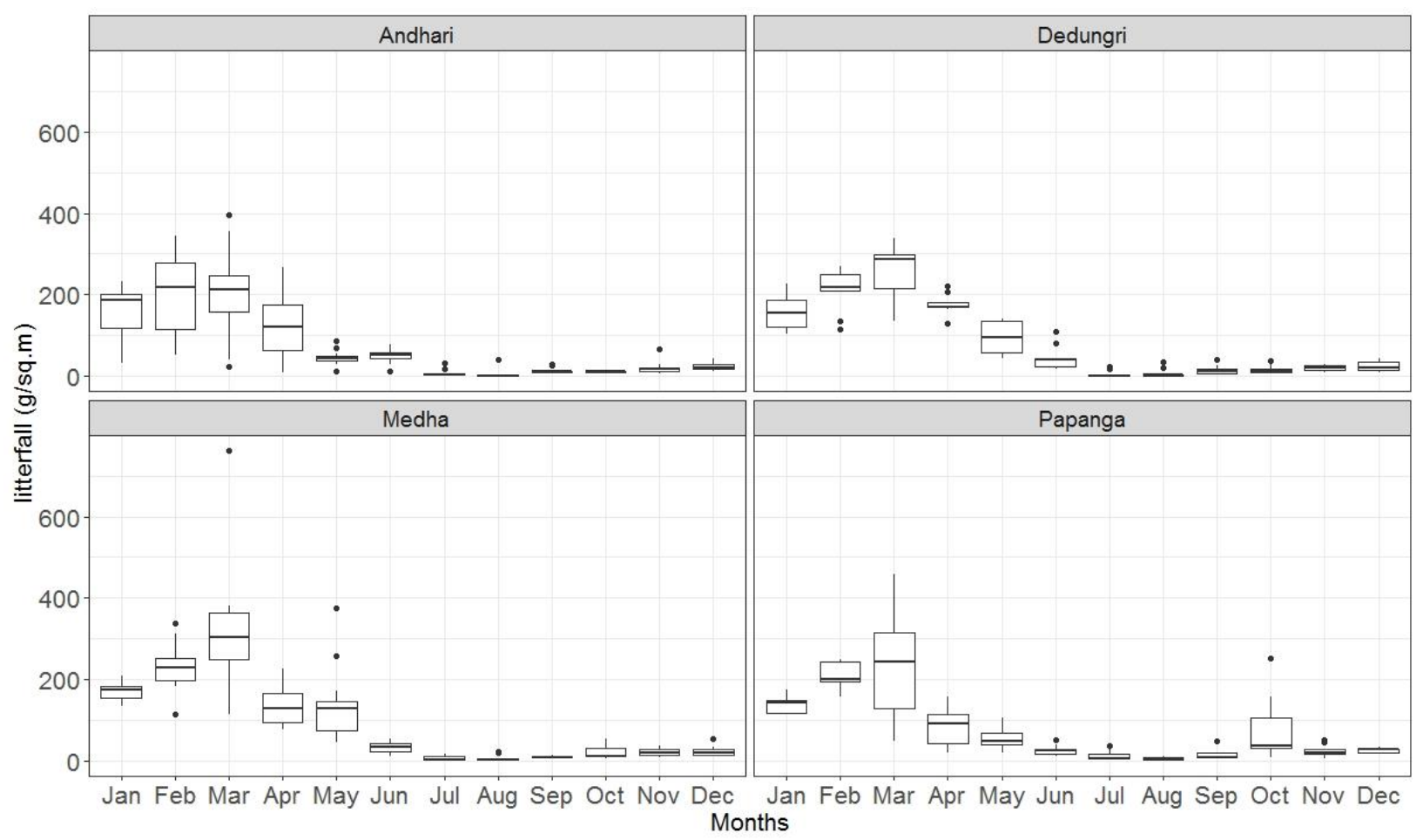

607 Figure 3. Monthly variation of litterfall $\left(\mathrm{g} / \mathrm{m}^{2}\right)$ in different sacred forests.

608

609

610

611

612

613

614

615

616

617

618

619 

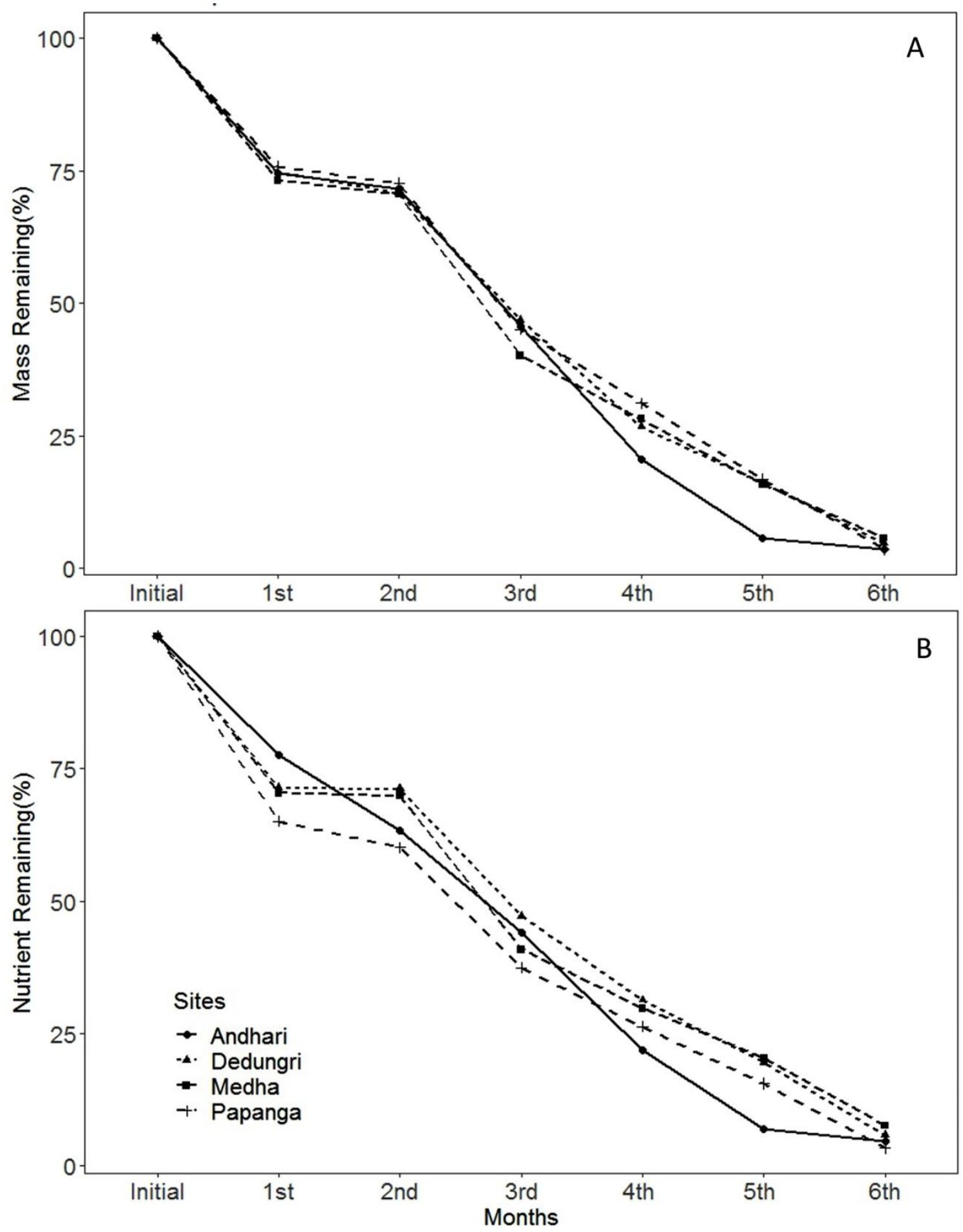

621

622 Figure 4. Trends of remnant litter mass and nutrients during the period of decomposition

623 in different sites; A) Mass remains, B) Nutrient remains. 


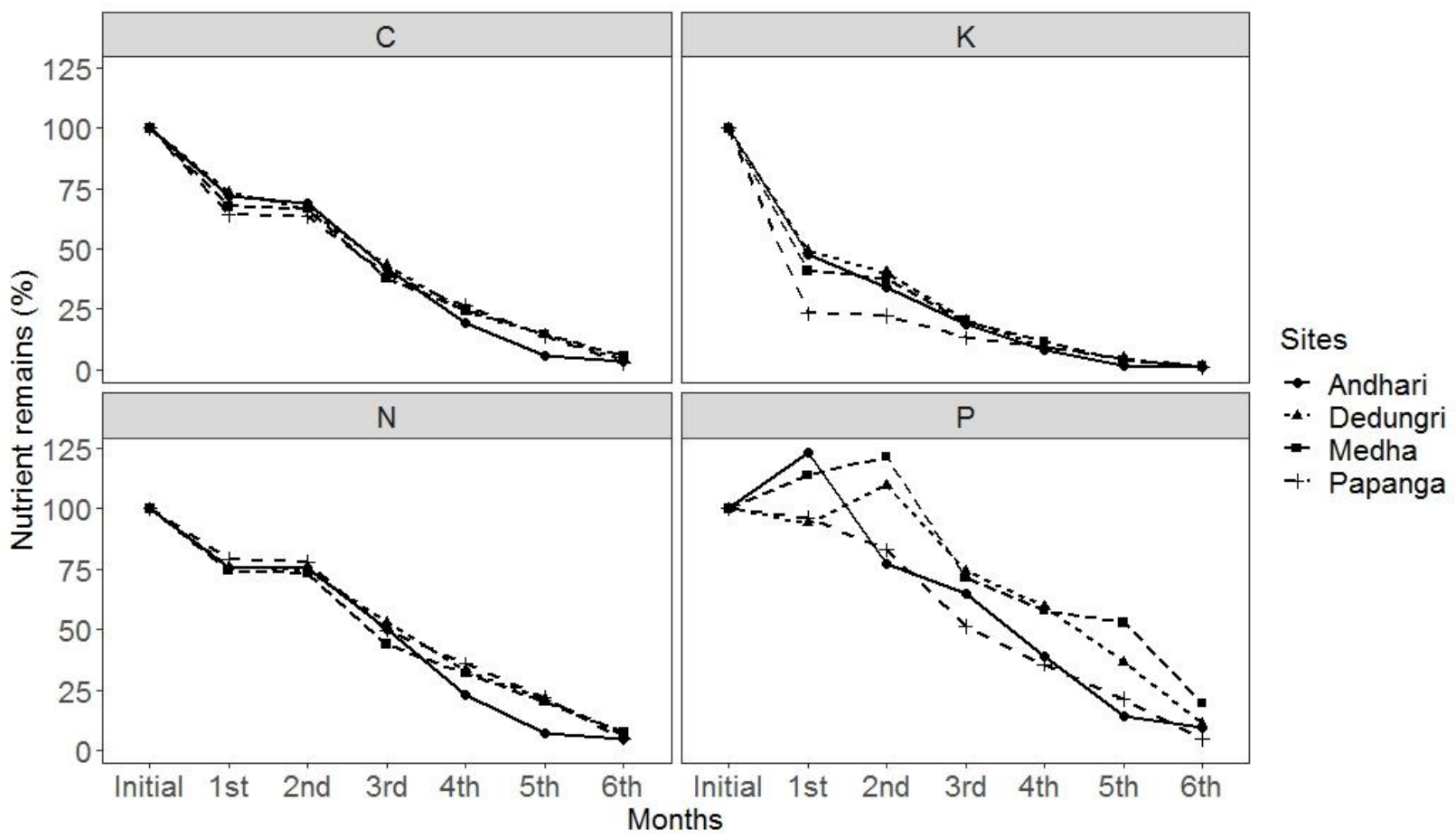

624

625 Figure 5. Nutrient loss or remains during the decomposition period.

626 
Figures

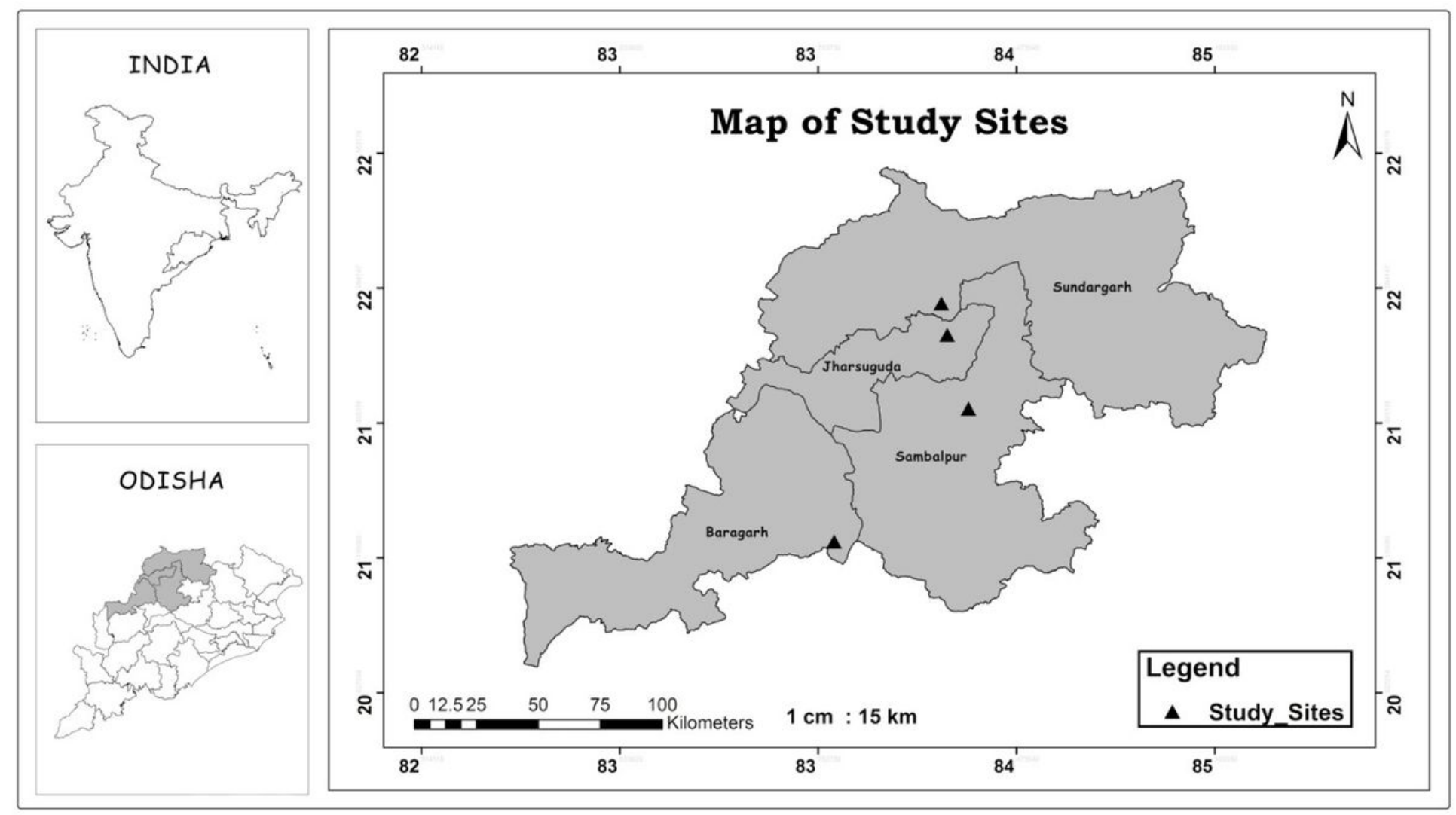

Figure 1

Location of Study sites in four different districts (Sundergarh, Jharsuguda, Sambalpur and Bargarh) of Odisha. 


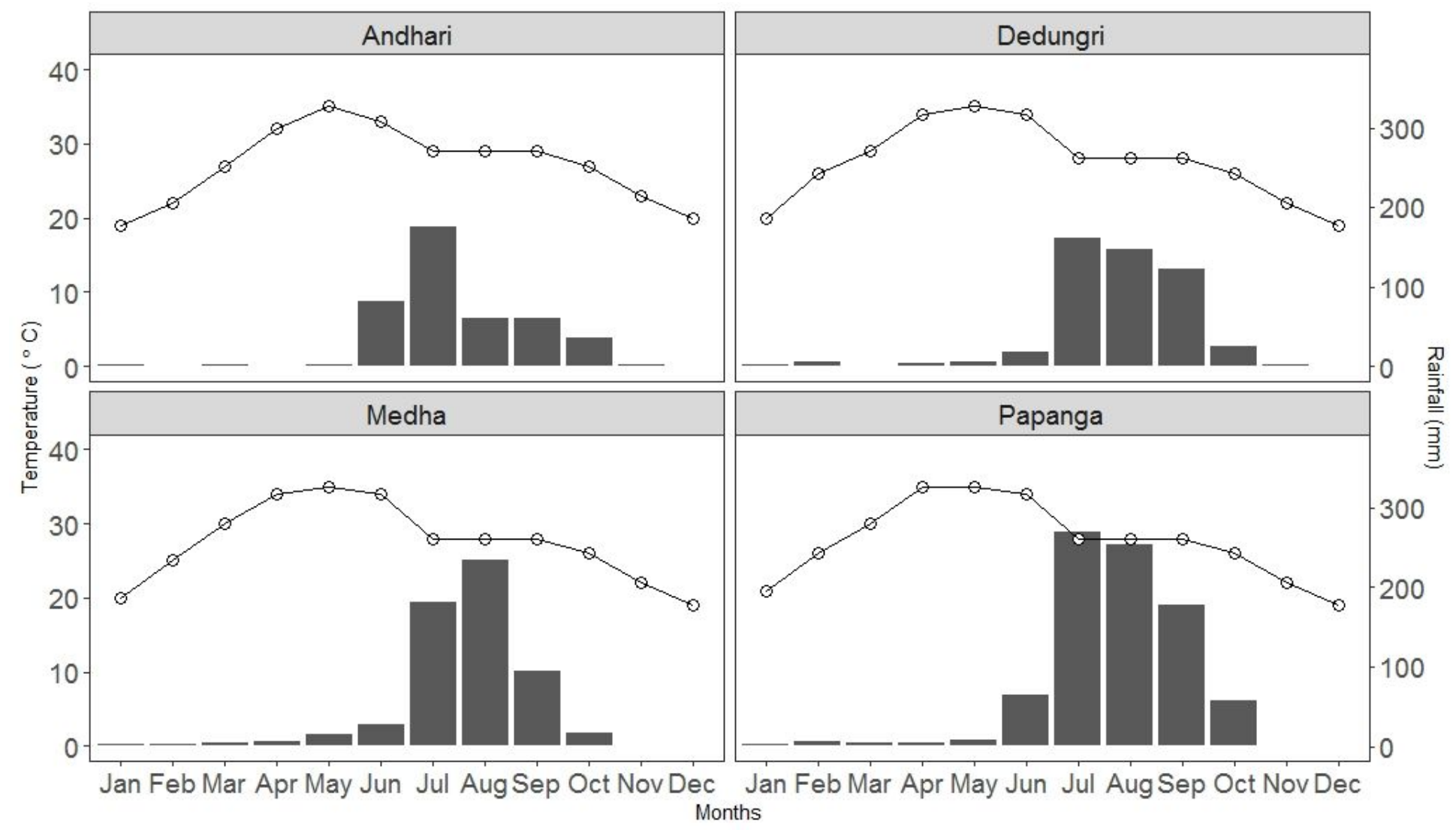

\section{Figure 2}

Average monthly temperature and rainfall of the study sites for 2017.

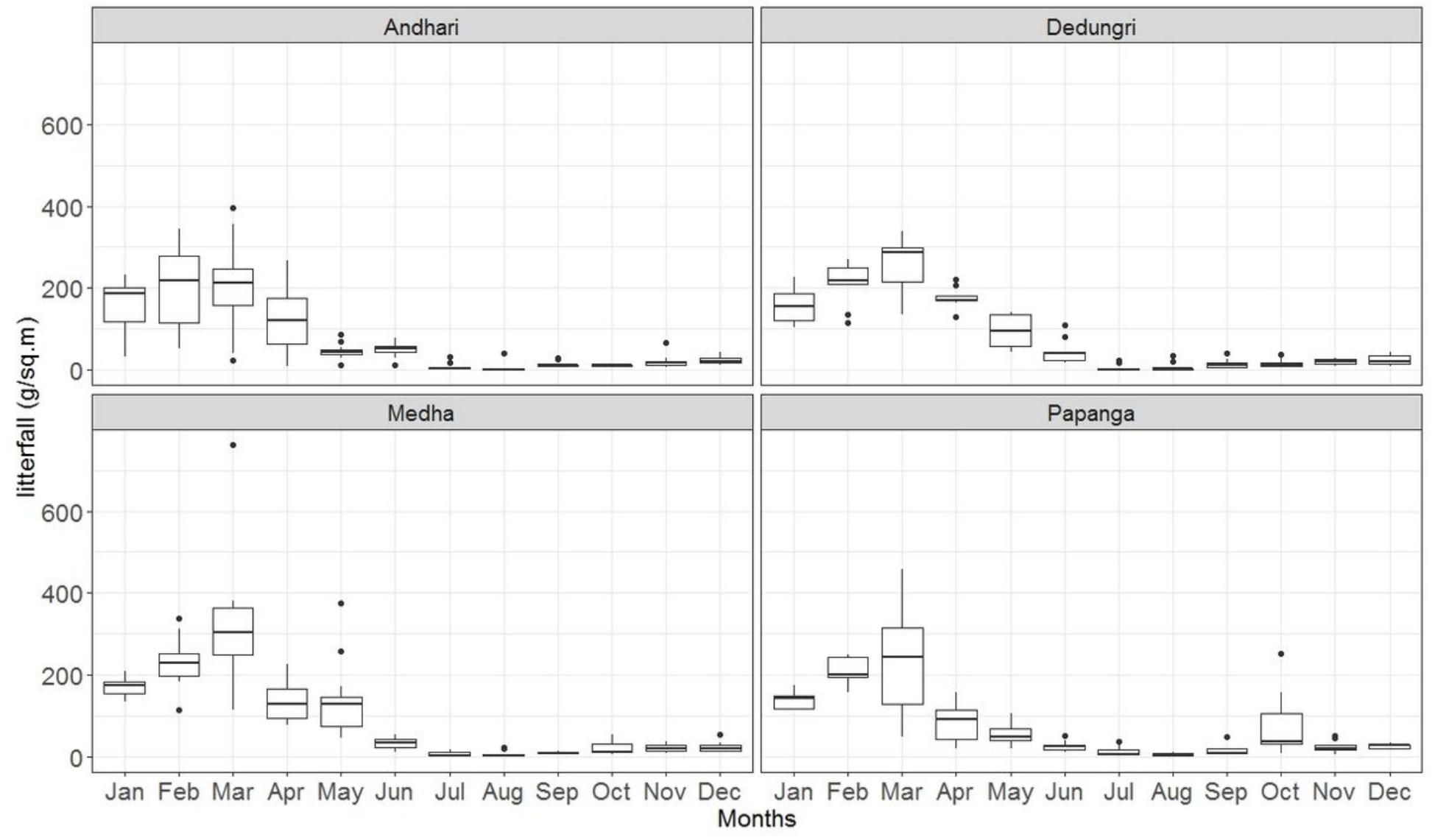


Figure 3

Monthly variation of litterfall $(\mathrm{g} / \mathrm{m} 2)$ in different sacred forests.
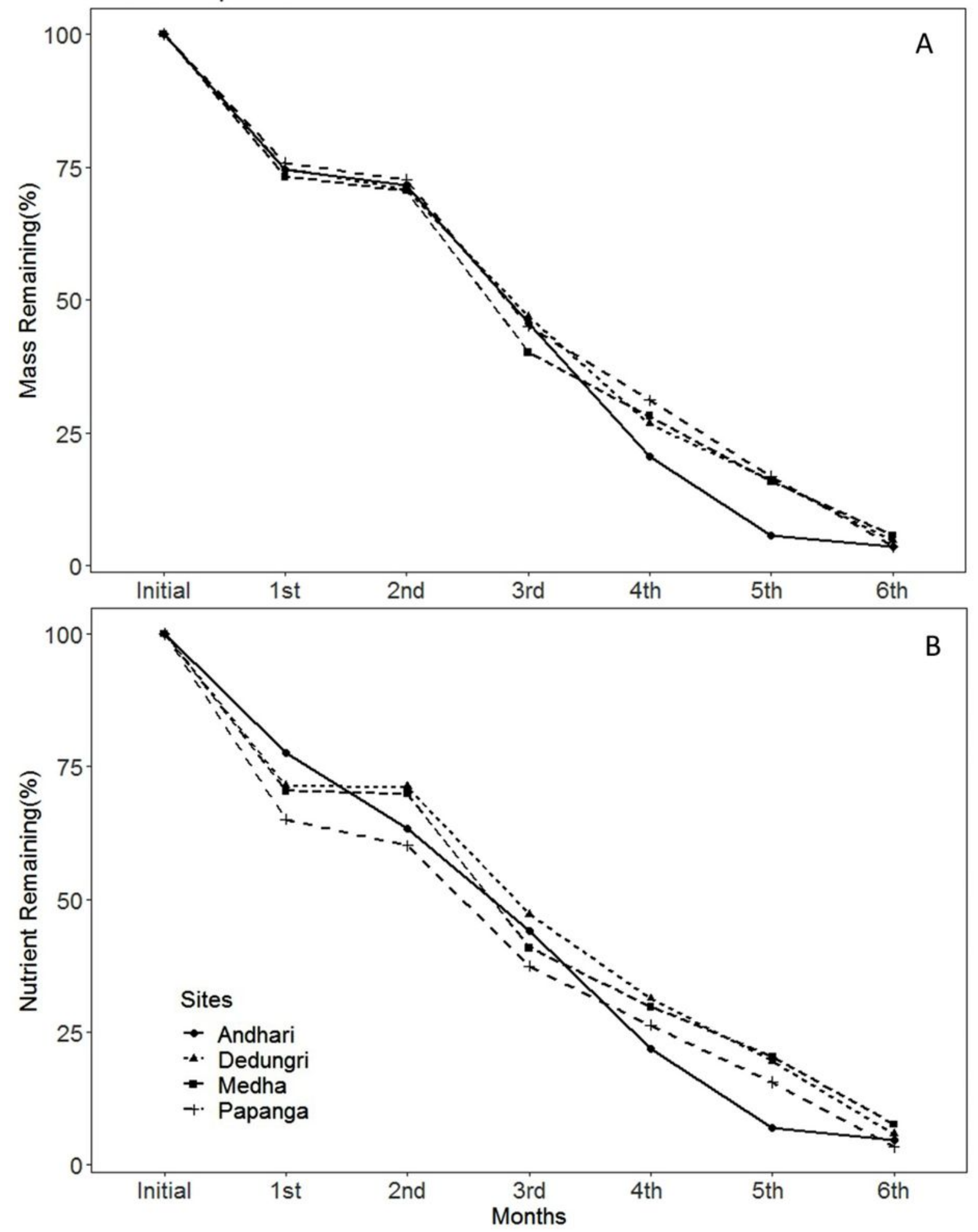

\section{Figure 4}

Trends of remnant litter mass and nutrients during the period of decomposition in different sites; A) Mass remains, B) Nutrient remains. 


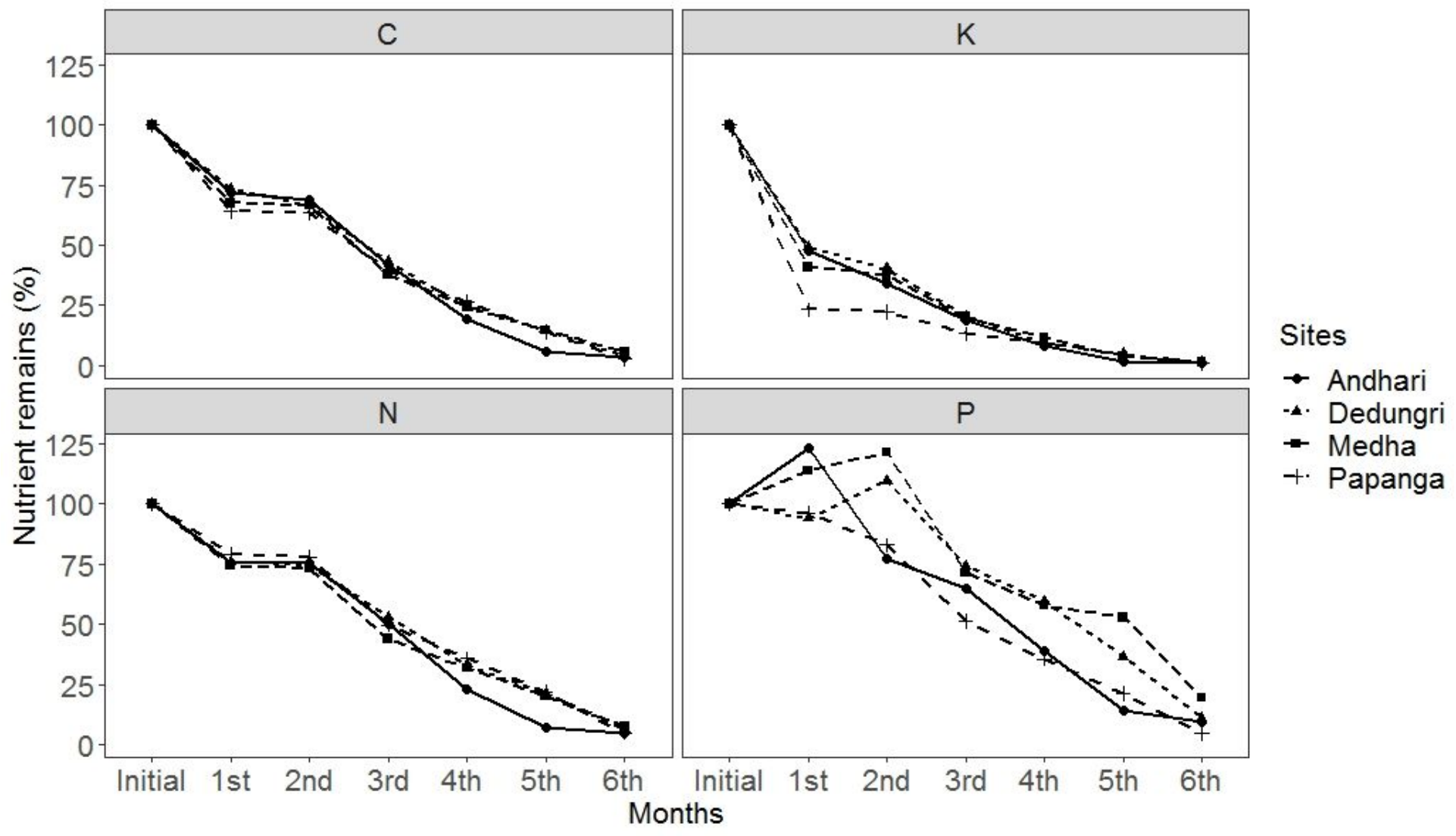

Figure 5

Nutrient loss or remains during the decomposition period. 